\title{
Anticancer and apoptosis-inducing activities of microbial metabolites
}

\author{
Sirinet Phonnok ${ }^{1} \cdot$ Wanlaya Uthaisang Tanechpongtamb $^{1}$ \\ Benjamas Thanomsub Wongsatayanon ${ }^{1} \square$
}

1 Department of Microbiology, Faculty of Medicine, Srinakharinwirot University, Bangkok, Thailand

2 Department of Biochemistry, Faculty of Medicine, Srinakharinwirot University, Bangkok, Thailand 10110

$\triangle$ Corresponding author: benjamat@swu.ac.th

Received March 2, 2010 / Accepted May 11, 2010

Published online: September 15, 2010

(c) 2010 by Pontificia Universidad Católica de Valparaíso, Chile

\begin{abstract}
The problems of systemic toxicity and drug resistance in cancer chemotherapy urge the continuing discovery of new anticancer agents. We explored the specific anticancer activity from microbial metabolites to find new lead compound. 394 microbial extracts were evaluated on anti-proliferative activity against 4 cancer cell lines using MTT assay. Of these, 20 samples showed varying degree of cytotoxicity but specifically to the cancer cell lines since the growth of normal cells was not significantly inhibited by $1 \mathrm{mg} / \mathrm{ml}$ of each cell extracts. The 4 most potent extracts exhibited strongest growth inhibition to each cancer cell type were selected for further studied. Cell morphological changes such as cell shrinkage, lose of surface contact and blebbing were observed in all treated cancer cells. DNA-binding dye staining demonstrated nuclear condensation and fragmentation. Chromosomal DNA cleavage detected as DNA ladder pattern by gel electrophoresis including activation of cellular caspase-3 activity, a hallmark of apoptosis, were observed in all treated cancer cell lines. These characteristics suggested the mechanism of apoptosis cell death induced by the extracts. No growth inhibition and apoptosis characteristic were detected in normal cells even at high concentration used suggesting the selective cytotoxicity and potential candidates to develop as anticancer agents.
\end{abstract}

Keywords: anticancer, apoptosis, bioactive compound, caspase, microbial product

\section{INTRODUCTION}

Natural resources, such as plants, microorganisms, vertebrates and invertebrates, are valuable source of bioactive compounds. A large number of drugs have been developed in medicinal practice from natural products (Amador et al. 2003). Since the discovery and success in the treatment of penicillin, microorganisms have been especially used as a privileged source of structurally diverse bioactive agents. The therapeutic application of microbial metabolites provided the opportunity for the discovery of antibiotics (e.g., penicillin, erythromycin, streptomycin, amphotericin and polyketides), immunosuppressants in transplantation (e.g., cyclosporine A, FK506 and 
rapamycin), cholesterol lowering agents (e.g., lovastatin and mevastatin) and anticancer agent (e.g., daunorubicin, doxorubicin, bleomycin and pentostatin).

Cancer appears to be a major cause of morbidity and mortality and runs in the top three cause of death worldwide especially in the developed countries (WHO, 2009). Chemotherapy is one of the potent treatments for prolonging the patient's life. Almost $60 \%$ of anticancer drugs are of natural origin, such as plants (i.e., vincristine, irinotecan, camptothecines) and microorganisms (i.e., doxorubicin, dactinomicines, mitomycin and bleomycin) (Grever, 2001). However, many chemotherapeutic drugs are presently placed in a predicament of reduced therapeutic effect due to the

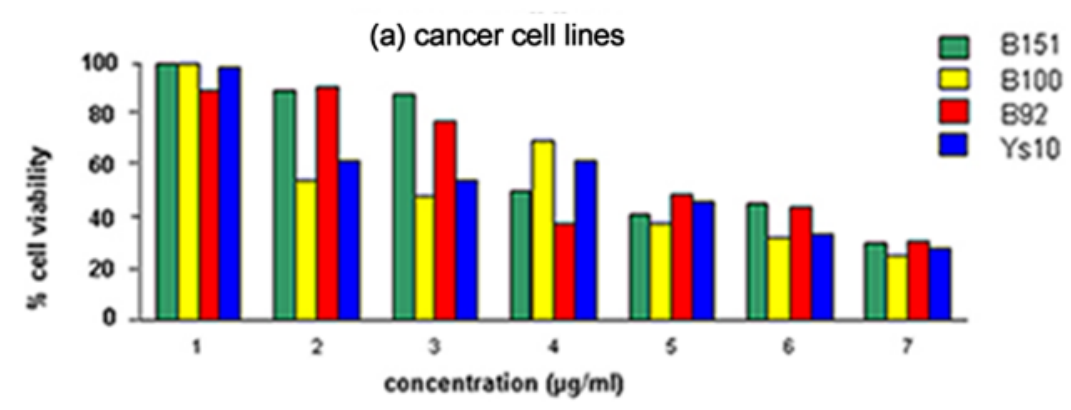

(b) vero cells

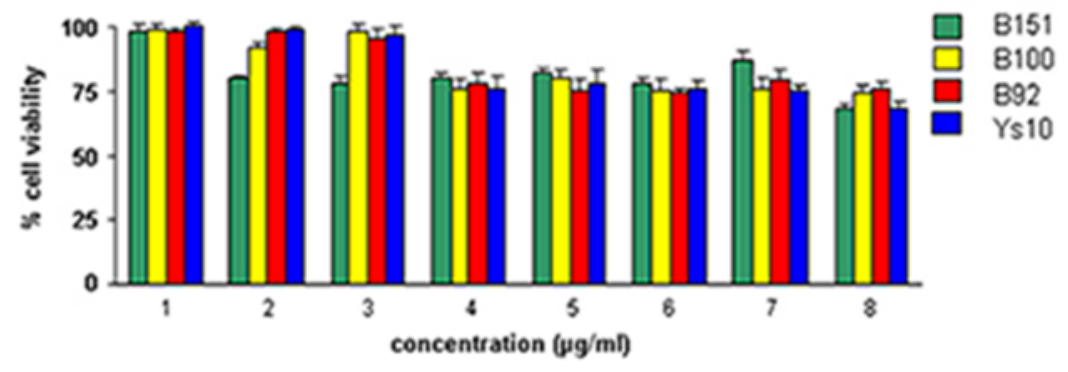

(c) PBMC

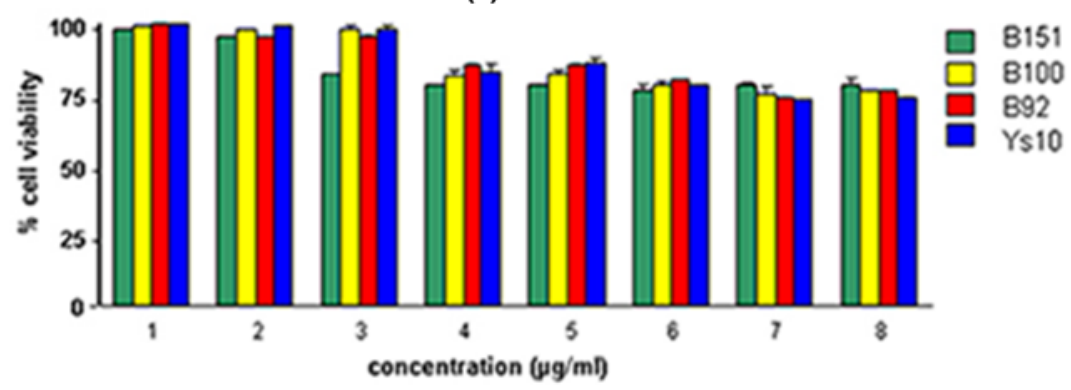

Fig. 1 Dose response curves of active crude extracts derived from the B151, B100, B92, and Ys102 strains, respectively after $48 \mathrm{hrs}$ of incubation against (a). cancer cell lines: HepG2(1), MCF-7(2), HeLa(3) and U937(4); (b). Vero cells and (c). PBMC. Results are means \pm SD from three independent experiments. 
problem of drug-resistance (Peters et al. 2002). Moreover, chemotherapeutic drugs also exert toxicity to normal cells which in turn causes the unpleasant side effects to the patients. For these reasons, research and development for new classes of anticancer agents which exhibit efficient and selective toxicity on tumor cells is attracting increased attention. Among various sources of anticancer drugs, microorganisms have more advantages regarding to the potentials in producing diverse compounds and in manipulation of the production.

In this study, we aimed to find a new source of low or non toxic natural anticancer agent produced by microorganisms isolated from various sources and used their culture extracts to screen for the cytotoxicity specific to cancer cell lines. MTT (3- $(4,5-$ Dimethylthiazol-2-yl)-2,5-diphenyltetrazolium bromide) assay which measuring the mitochondrial reductase enzymeactivity of viable cells that could reduce MTT to formazan, giving a purple color, was used for screening cytotoxicity. Some extracts exhibited cytotoxicity and showed apoptosis-induced cell death to cancer cells which is the critical property for an anticancer lead compound.

Table 1. The $I C_{50}$ values of the positive extracts. All these crude extracts did not showed

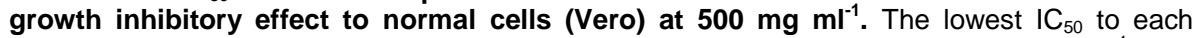
cancer type were represented in bold. (-) means no cytotoxicity was found at $500 \mathrm{\mu g} \mathrm{m}^{-1}$. The different alphabets superscript showed the significant difference of treatments in the same cancer cell line.

\begin{tabular}{|c|c|c|c|c|}
\hline \multirow{2}{*}{$\begin{array}{c}\text { Microorganism/ } \\
\text { extract }\end{array}$} & \multicolumn{4}{|c|}{$I C_{50}(\mu \mathrm{g} / \mathrm{ml})$} \\
\hline & MCF-7 & HepG2 & HeLa & U937 \\
\hline Ys102 & - & - & - & $23.22 \pm 1.78^{a}$ \\
\hline B92 & - & $110.3 \pm 1.8^{\mathrm{e}}$ & $93.68 \pm 1.07^{a}$ & - \\
\hline B151 & $130.7 \pm 1.05^{d}$ & $79.3 \pm 1.52^{a}$ & - & - \\
\hline B100 & $21.18 \pm 1.40^{a}$ & $89.86 \pm 1.08^{d}$ & - & - \\
\hline B89 & $162.4 \pm 0.7^{\dagger}$ & - & - & - \\
\hline BFW9 & $168.6 \pm 0.44^{g}$ & - & - & - \\
\hline B136 & $331.7 \pm 0.71^{j}$ & - & - & - \\
\hline B110 & $239.7 \pm 1.41^{h}$ & - & - & - \\
\hline B120 & $438.7 \pm 1.4^{\mathrm{m}}$ & - & - & - \\
\hline B129 & $155.9 \pm 0.74^{\mathrm{e}}$ & - & - & - \\
\hline ВСM6 & $219.5 \pm 0.8^{i}$ & - & - & - \\
\hline B111 & $202.1 \pm 0.7^{\mathrm{h}}$ & - & - & - \\
\hline B91 & $372.9 \pm 2.0^{k}$ & - & - & - \\
\hline Y12 & $52.2 \pm 0.71^{b}$ & - & - & $43.26 \pm 0.16^{b}$ \\
\hline B189 & $409.1 \pm 1.07^{\prime}$ & - & - & $75.85 \pm 1.52^{d}$ \\
\hline Y238 & - & - & - & $83.66 \pm 0.77^{e}$ \\
\hline B107 & - & $86.2 \pm 0.78^{c}$ & - & $186.44 \pm 0.78^{f}$ \\
\hline B105 & $88.51 \pm 0.41^{c}$ & - & $193 \pm 0.45^{b}$ & $45.02 \pm 1.18^{c}$ \\
\hline $\begin{array}{l}\text { S. marcescens } \\
\text { B. subtilis }\end{array}$ & - & $\begin{array}{l}138.9 \pm 1.45^{\dagger} \\
81.08 \pm 0.77^{b}\end{array}$ & - & - \\
\hline Doxorubicin & $0.66 \pm 0.22$ & $2.40 \pm 0.8$ & $1.41 \pm 0.47$ & $2.47 \pm 0.08$ \\
\hline
\end{tabular}




\section{MATERIALS AND METHODS}

\section{Microorganism isolation and crude extract preparation}

The bacteria and yeast were isolated from the collected samples of oil contaminated soils, water, plant materials and clinical samples. The pure microorganisms were grown in liquid basal oil medium (4\% soy bean oil, $0.05 \%$ yeast extract, $0.3 \%$ $\mathrm{NH}_{4} \mathrm{NO}_{3}, 0.02 \% \mathrm{KH}_{2} \mathrm{PO}_{4}$ and $0.02 \% \mathrm{MgSO}_{4} .7 \mathrm{H}_{2} \mathrm{O}$ ) and incubated in a shaker incubator at $200 \mathrm{rpm}$ at $37^{\circ} \mathrm{C}, 48 \mathrm{hrs}$ for bacteria or at $30^{\circ} \mathrm{C}, 72 \mathrm{hrs}$ for yeast. The crude extracts were prepared from whole cultures; containing cells and broths by ethyl acetate, evaporated and dissolved in methanol and washed twice with hexane (Thanomsub et al. 2006). The crude extracts from methanol fraction were kept at $4^{\circ} \mathrm{C}$ until use for cytotoxic assay.

\section{Cell lines and culture conditions}

Cervical cancer (HeLa), liver cancer (HepG2) breast cancer (MCF-7), monocytic leukemia (U937) and African green monkey kidney (Vero) cell lines were from American Type Culture Collection (ATCC). The medium used for HepG2, MCF-7 and HeLa cell lines was Dulbecco's modified Eagle's medium (DMEM, GIBCO, USA), for U937 was RPMI1640 and for Vero was M199. All cells were supplemented with $10 \%$

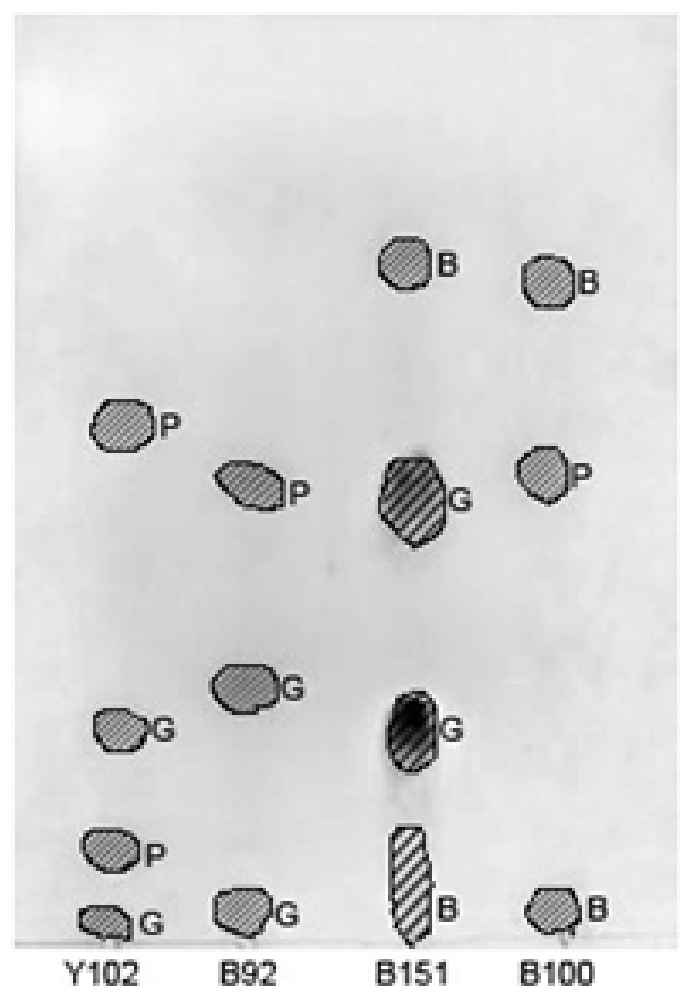

Fig. 2 TLC chromatogram of $10 \mu \mathrm{g}$ the potent crude extracts spotted onto a silica gel plate, developed by the solvent system of chloroform/methanol/water $(65: 25: 2, \mathrm{v} / \mathrm{v})$ and visualized by anisaldehyde spray. G: green; B: Blue; P: purple. 
fetal bovine serum and $100 \mathrm{U} / \mathrm{ml}$ of penicillin-streptomycin and incubated at $37^{\circ} \mathrm{C}$ and $5 \% \mathrm{CO}_{2}$. Whole blood was taken from 3 healthy individual subjects and peripheral blood mononuclear cells (PBMC) were separated by Ficoll Plague Premium reagent kit (GE Healthcare Bio-Sciences AB, Sweden) and maintained in RPMI medium.

\section{Cytotoxicity assay}

Ninety $\mu \mathrm{l}$ containing $1.0 \times 10^{4}$ cells of cell line suspension (MCF-7, HepG2, HeLa, U937, Vero cells and PBMC) were seeded into wells of a 96-well plate. After 24 hrs of incubation, $10 \mu \mathrm{l}$ of crude extracts dissolved in $0.01 \%$ ethanol were added to final concentration 500 or $1,000 \mu \mathrm{g} / \mathrm{ml}$ and incubated for another $48 \mathrm{hrs}$. The cytotoxicity test was determined by MTT (3-(4,5-Dimethylthiazol-2-yl)-2,5-diphenyltetrazolium bromide) assay (Flis et al. 2009). In brief, $50 \mu$ l of MTT was added to the wells, the cells were cultured for additional $4 \mathrm{hrs}$ at $37^{\circ} \mathrm{C}$. Then $100 \mu \mathrm{l}$ of $10 \%$ SDS was added to the wells. The solubilized formazan was measured at $595 \mathrm{~nm}$ using microplate spectrophotometer (Multiskan, Finland). Each treatment was assayed in triplicate. Three independent preparations of crude extracts and MTT assays were performed. Doxorubicin and $0.01 \%$ ethanol (vehicle control) were used as positive and negative controls, respectively. Statistical analysis between treatment and control was determined using paired two-tailed Student's $t$-test. $P$-values $<0.05$ were considered significantly different from the control group. The cytotoxicity of the crude extract was expressed as $I_{50}$ value (concentration exhibited $50 \%$ cytotoxicity). The significant difference of $\mathrm{IC}_{50}$ of crude extracts against the same cell line was compared using one way ANOVA, PostHoc test.

\section{Qualitative analysis of active crude extracts}

The methanol crude extracts prepared from $100 \mathrm{ml}$ of spent culture broths of the potent strains were dissolved with methanol to final concentration of $10 \mathrm{mg} / \mathrm{ml}$ and 1 $\mu \mathrm{l}$ was spotted onto silica gel TLC. The TLC plate was run in TLC tank containing chloroform/ methanol/ water $(65: 25: 2, \mathrm{v} / \mathrm{v})$. The bands were visualized by ninhydrin $(0.2 \%$ in ethanol), rhodamine $6 \mathrm{G}(0.001 \%$ in acetone $)$, iodine vapor and $\rho$ anisaldehyde- $\mathrm{H}_{2} \mathrm{SO}_{4}(0.5 \%$ in acid ethanol) sprays to detect the active group composition in the extracts (Krebs et al. 1969).

\section{Morphology of apoptosis cell death observation}

After treatment the cells with or without microbial crude extracts for $48 \mathrm{hrs}$, the media were removed and washed 3 times with PBS. The cells were then observed underphase contrast inverted microscope (Nikon, Japan). For DNA staining experiment, $50 \mu \mathrm{l}$ of $100 \mu \mathrm{g} / \mathrm{ml}$ Hoechst 33342 was added, incubated at $37^{\circ} \mathrm{C}$ for 10 min and examined under fluorescence inverted microscope at emission wavelength $461 \mathrm{~nm}$ (Olympus, Japan).

\section{DNA ladder assay}

Cancer cells at $3 \times 10^{6}$ cells were treated with the extracts at concentrations which induced $70 \%$ cytotoxicity and incubated at $37^{\circ} \mathrm{C}, 5 \% \mathrm{CO}_{2}$ for $24 \mathrm{hrs}$. At the incubation time ended, the chromosomal DNA of cancer cells was prepared with Apoptotic DNA Ladder Kit (Roche, cat. No.1835246001). Cells were harvested and lysed with lysis 
buffer for $10 \mathrm{~min}$. Then the samples were mixed with isopropanol before passing through the filter and washed. The DNA was eluted from the filter and treated with RNAse at $37^{\circ} \mathrm{C}$ for 30 min before loading onto $2 \%$ agarose gel electrophoresis and run $50 \mathrm{~V} / \mathrm{cm}$ for $3 \mathrm{hrs}$. The normal cells treated with the potent microbial extracts at $500 \mu \mathrm{g} / \mathrm{ml}$ were also examined. The non-treated cancer cells and the positive of apoptosis cells were extracted and run in parallel.

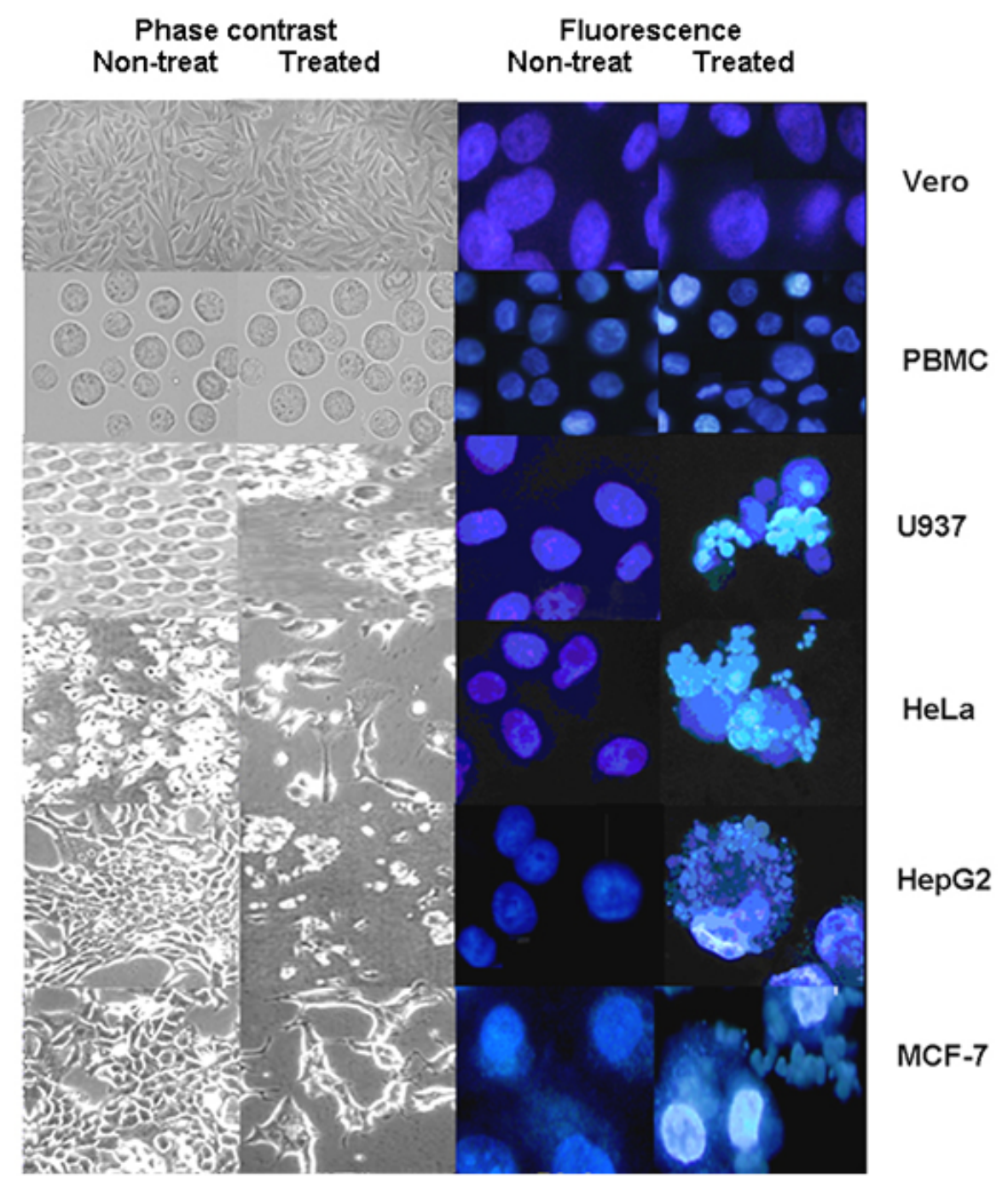

Fig. 3. Cell morphology and DNA staining of normal cells (Vero and PBMC) and various cancer cells after $48 \mathrm{hrs}$ of treatment with $500 \mu \mathrm{g} / \mathrm{ml}$ ofYs102, B92, B151 and B100 crude extracts (treated), running from top and $0.01 \%$ ethanol (vehicle control, untreated) observed under phase contrast microscope (left panel) and fluorescence inverted microscope (right panel) at the magnification of $400 \mathrm{X}$. 


\section{Caspase-3 activity assay}

The caspase- 3 activity was assayed using CaspACE тм Assay System, Colorimetric (Biovision, USA). $3 \times 10^{6}$ cells of cancer cells or normal cells treated with or without the extracts at $37^{\circ} \mathrm{C}, 5 \% \mathrm{CO}_{2}$ for $24 \mathrm{hrs}$ were pellet by centrifugation and resuspended with lysis buffer. The cell lysate was incubated on ice for 10 min prior to centrifugation (15,000 rpm, $1 \mathrm{~min})$. The reaction buffer, with $10 \mathrm{mM}$ DTT was added to the supernatant of cell lysate and incubated further $30 \mathrm{~min}$ on ice. Control was prepared by adding $1 \mu \mathrm{l}$ of $1 \mathrm{mM}$ Z-VAD-fmk (pan-caspase inhibitor) to the cell sample treated with the extracts. Five microlitres of caspase-3 substrate (Ac-DEVDpNA) was added to all tubes and incubated at $37^{\circ} \mathrm{C}$ for $1 \mathrm{hr}$. The p-nitroanilide product was measured at $405 \mathrm{~nm}$ by spectrophotometer (Thermo electron Co., China). Statistical analysis between treatment with and without inhibitor was determined using paired two-tailed Student's $t$-test with $P$-values $<0.05$ were considered as significant difference.

\section{RESULTS AND DISCUSSION}

\section{Screening of microbial extracts that show cancer cell-specific cytotoxicity}

A total of 394 microorganisms of bacteria and yeasts were isolated from various sources, including oil-contaminated soils, plant materials, water and clinical samples. The liquid basal oil medium which is generally used for biosurfactant production in our lab was used for microbial cultivation. For preliminary screening, whole culture broth was used for crude extract preparation by organic solvent fractionation such as ethyl acetate, methanol and hexane. The cytotoxic activity of the microbial crude extracts was determined against four established cancer cell lines; MCF-7, HepG2, HeLa and U937 cells and Vero cell as a representative of normal cell line. The cell extracts that showed highest cytotoxicity to each cancer cell type were selected. Through this screening, thirty-five extracts accounting for $8.9 \%$ of total samples tested showed the cytotoxic effect and most of these samples were derived from the bacterial cultures (31 of 35 isolates). Of these, 20 samples exhibited cytotoxicity specifically to the cancer cell lines (5\% of total samples). The $\mathrm{IC}_{50}$ values of these extracts against cancer cell lines were in range of $21-438 \mu \mathrm{g} / \mathrm{ml}$, whereas the growth of non-cancer normal cell line (Vero) was not significantly inhibited by $500 \mu \mathrm{g} / \mathrm{ml}$ of each cell extract (Table 1 ). We selected the most potent extracts which exhibited the lowest IC $\mathrm{C}_{50}$ (21$79 \mu \mathrm{g} / \mathrm{ml}$ ) to each cancer cell line for further studied (Table 1). The 26s and 16s rRNA sequences analyses of these strains suggested that Ys102, B92, B151 and B100 belong to Candida tropicalis, Acinetobacter baumannii, Pseudomonas aeruginosa and Bacillus sp., respectively. The cytotoxic effects of their extracts were in a dosedependent manner (Figure 1). Doxorubicin, a commercial anticancer drug, showed $\mathrm{IC}_{50}$ against cancer cell lines at $0.66-2.5 \mu \mathrm{g} / \mathrm{ml}$ (Table 1 ) and $25.7 \mu \mathrm{g} / \mathrm{ml}$ to normal cell (data not shown), while treatment of normal cells with $1,000 \mu \mathrm{g} / \mathrm{ml}$ of microbial extracts showed no significant anti-proliferative effect (P-value at 0.05 ) (Figure 1). The normal and cancer cells treated with $0.01 \%$ ethanol (vehicle control) had no cytotoxic effect to all cancer cells and normal cell tested (data not shown).

There was some reports on $P$. aeruginosa and Bacillus $s p$. in producing some biologically active compounds against cancer cell lines (Thanomsub et al. 2006; Kim et al. 2007; Ohba et al. 2009), but none from Candida tropicalis and Acinetobacter baumannii. These two microorganisms are thus of our interest. 


\section{TLC analysis of cell extracts}

As a preliminary study on the constituents of the extracts, we compared the composition of cell extracts by silica gel TLC analysis followed by visualization with various detection sprays. Ninhydrin was used for the detection of amino acids and amines. $\rho$-anisaldehyde, iodine vapor, and rhodamine $6 \mathrm{G}$ were used for the detection of oxygenated compounds such as sugar and lipid. All of the potent extracts were positive with $\rho$-anisaldehyde- $\mathrm{H}_{2} \mathrm{SO}_{4}$ (Figure 2), iodine, and rhodamine $6 \mathrm{G}$ (data not shown), suggesting the presence of sugar and lipid moieties-containing compounds. By $\rho$-anisaldehyde-staining, the spots appeared in green, blue and purple, suggesting that the sugar moieties might be rhamnose, ribose or mannose (Sassaki et al. 2008).

A

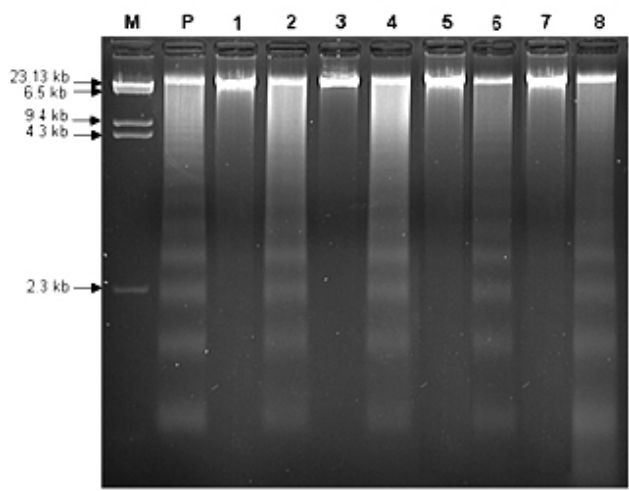

B

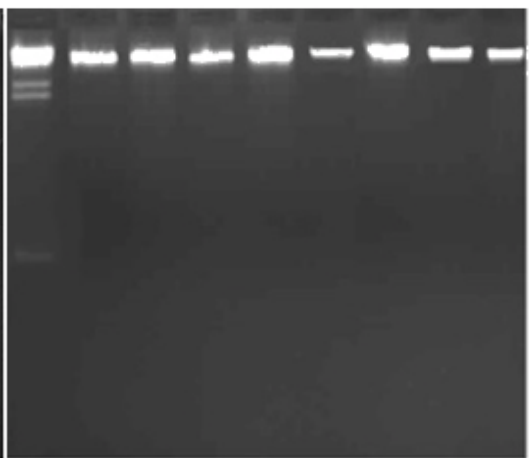

Fig. 4 Agarose gel electrophoresis of chromosomal DNA of $3 \times 10^{6}$ cells of (A) variouscancer cells and (B) normal cells treated with the extracts at $37^{\circ} \mathrm{C}$ for $24 \mathrm{hrs}$ in 5\% $\mathrm{CO}_{2}$. (A) $\mathrm{M}=$ molecular weight marker; $\mathrm{P}=$ Positive control; lane 1, U937 cells untreated; lane 2, U937 treated with Ys102 extract; lane 3, HeLa untreated; lane 4, HeLa with B92 extract; lane 5, HepG2 untreated; lane 6, HepG2 cells with B151 extract; lane 7, MCF-7 untreated; and lane 8, MCF-7 treated with B100 extract. (B) M = molecular weight marker; lane 1, PBMC treated with Ys102 extract; lane 2, Vero cells treated with Ys102 extract; lane 3, PBMC treated with B92 extract; lane 4, Vero cell treated with B92 extract; lane 5, PBMC treated with B151 extract; lane 6, Vero cell treated with B151 extract; lane 7, PBMC treated with B100 extract; lane 8 , Vero cell treated with B100 extract.

As the cooking oil was used as sole carbon source for cultivation, it was possible that some components of the oil may have contributed to the synthesis of the bioactive compound. To test this possibility, we compared the activities produced by cultivation in the oil medium to those produced in the complete media such as yeast and mold (YM) and nutrient broth. For all of these strains, the cytotoxic activities produced in the complete medium were much lower than those produced in the medium supplemented with oil (data not shown). Therefore, it was possible that the active compounds may contain a component of lipids or glycolipids as a constituent. In fact, it was reported that some microorganisms cultured in basal oil medium produced glycolipid which showed anti-proliferative effect to cancer cells (Thanomsub et al. 2006; Kim et al. 2007). 


\section{Morphological effect of cell extracts on cancer cells}

For the preliminary characterization of the cytotoxicity induced by the microbial extracts in the cancer cells, we first examined the changes in cell morphology induced by the treatment under a phase contrast microscope. In all of the cancer cell lines, cell rounding up, cell shrinkage, membrane blebbing and loss of cell adhesion were induced by the microbial extracts (Figure 3). These cellular changes are the characteristics of the apoptotic induction of cell death. To further characterize the cell death induced by the microbial extracts, nuclear morphology was determined by
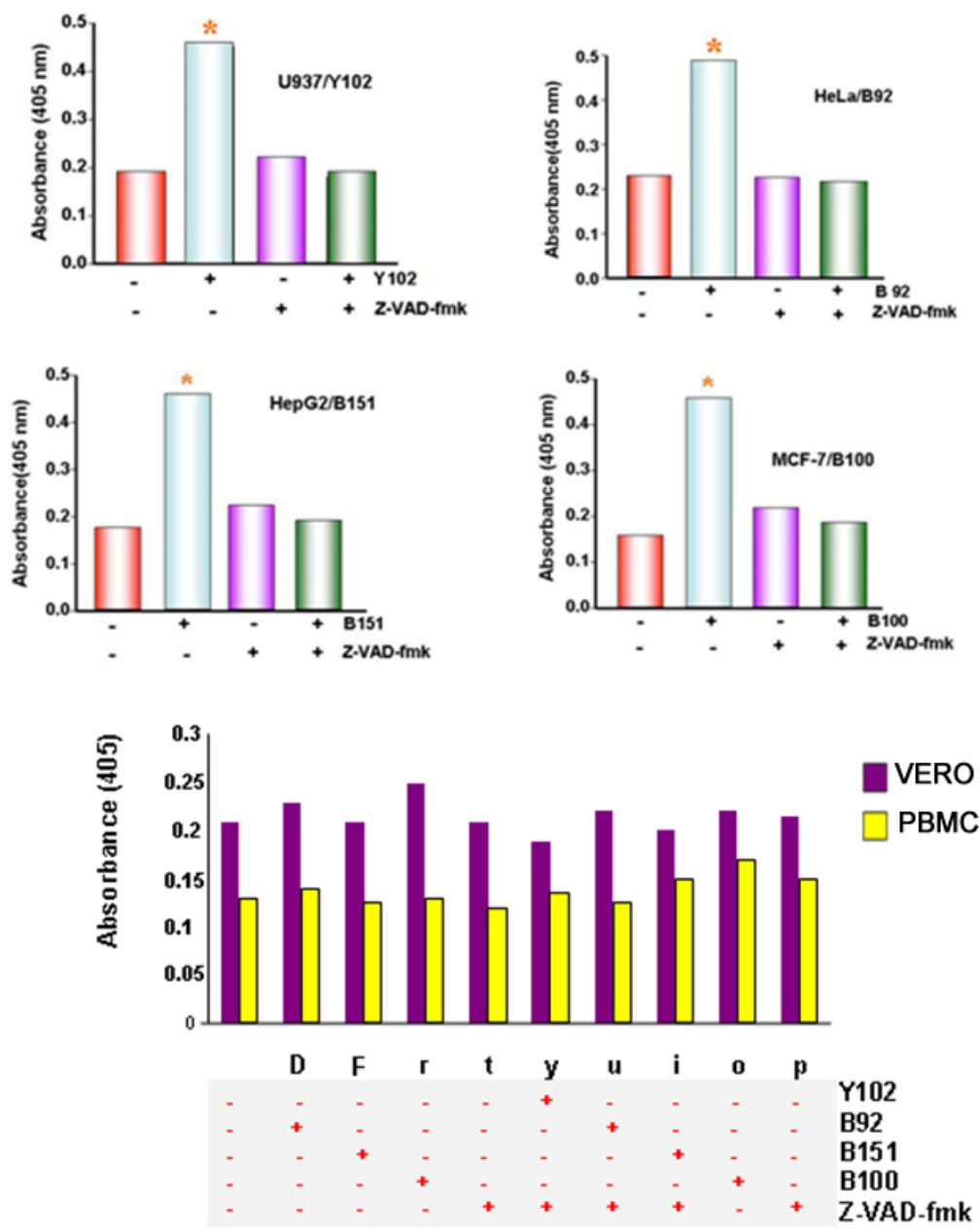

Fig. 5 Colorimetric assay of caspase-3 activity of cancer cells; U937, HeLa, HepG2 and MCF-7 and normal cells (bottom) treated with or without the microbial extracts at the concentration of $40 \mu \mathrm{g} / \mathrm{ml}$ Ys102; $125 \mu \mathrm{g} / \mathrm{ml}$ B92; $100 \mu \mathrm{g} / \mathrm{ml}$ B151; and $40 \mu \mathrm{g} / \mathrm{ml}$ B100 extracts, respectively at $37^{\circ} \mathrm{C}$ for $24 \mathrm{hrs}$. Z-VAD-fmk is a broad range caspase inhibitor. The results shown are the representatives of three independent experiments. The treated sample showed significantly increased $\left(^{*}\right)$ in caspase activity compared to those untreated and caspase inhibitor addition $(P<0.05)$. 
staining with the DNA-binding dye Hoechst33342, in the presence and absence of the microbial crude extracts. The results revealed that all of these cell extracts induced the nuclear condensation and cell fragmentation into apoptotic bodies, the distinct characteristics of apoptotic process, in all of the cancer cell types (Figure 3, treated panel). Thus, it was suggested that the mode of cell death triggered by microbial extract might be the process of apoptosis, which is recognized as a novel strategy for identification of anticancer drugs (Shougang et al. 2008; Hou et al. 2009). In contrast, no cell morphological abnormality and DNA fragmentation of normal cells treated with all of the extracts at $500 \mu \mathrm{g} / \mathrm{ml}$ were observed (Figure 3) suggested nontoxic effect of these extracts to normal cells.

\section{DNA fragmentation analysis}

We next examined the damages of DNA induced by the extracts by performing gel electrophoresis of chromosomal DNA of the cancer cells. As demonstrated in Figure 4 , the pattern of laddering was clearly observed only in the treated samples but none in the treated normal cells. This characteristic is commonly associated with apoptotic process, in which the DNA is cleaved into fragments of 180 nucleosomal units by the endogenous endonucleases, but not with other mode of cell death, necrosis, in which a smeared band pattern is produced (Zhivotosky and Orrenius, 2001).

\section{Caspase-3 activity assay}

The activity of caspases (cysteine-dependent aspartate-specific proteinase) which is known as an important biochemical feature in apoptotic signaling was further determined to investigate whether the apoptosis was induced by the extracts. Since caspase- 3 is the main downstream effecter caspase that is present in most cell types and plays an important role in the execution of apoptosis cell death by cleaving the cellular substrates (Kumar, 2007), we then compared its activity in treated and untreated control cells. The result showed that caspase- 3 was significantly activated in the treated cells (Figure 5). Moreover, the activity was blocked by the broad range caspase inhibitor Z-VAD-fmk, suggesting that the apoptosis signaling induced by the extracts was a caspase-dependent pathway. Both Vero and PBMC treated with the microbial extracts did not show caspase-3 activation (Figure 5).

Our result clearly demonstrated that the microbial crude extracts induced apoptosis as detected by apoptosis characteristics; DNA fragmentation and caspase-3 activation in various cancer cells which seem to account for anti-proliferative activity determined by the MTT assay. The cytotoxic responses of the cancer cells to all extracts were dose dependent. In addition, the extracts showed the specificity to cancer cell types. In normal cell, no anti-proliferative activity was observed even at 12-50 times concentration of microbial products were used. In addition, the microbial extracts specifically affected both slow- and fast-dividing cancer cells but not affected to both slow- and fast-growing normal cells; PBMC and Vero cells, respectively. Not only the specific cytotoxic effect to the cancer cells that made them as a good candidate to develop as antitumor agent, but also the preliminary demonstrated of apoptotic induction in cancer cells. It is well known that the defect in apoptotic process causes normal cells to turn into immortalized cancer cells. Thus, to induce apoptosis in cancer cells is an important feature that is expected for a new anticancer lead compound. The utilization of microbial fermentation products as anticancer agents is an advantage implement of bioactive compounds production as their abilities to control conditions in the laboratory and industrial scales. However, further 
investigations on the structure and mechanism of action of the bioactive compounds needs to be elucidated further.

\section{ACKNOWLEDGMENTS}

We are grateful to Dr. Chatsri Dechapanya, Faculty of Medicine, Srinakharinwirot University and Prof. Kyoya Takahata, Okayama University for providing MCF-7 and U937 cell lines, respectively. We also thank to Professor Tokichi Miyakawa for his kind assistance in critically reading the manuscript.

Financial support: This research was financially supported by Srinakharinwirot University grant.

\section{REFERENCES}

AMADOR, M.L.; JIMENO, J.; PAZ ARES, L.; CORTES FUNES, H. and HIDALGO, M. Progress in the development and acquisition of anticancer agents from marine sources. Annals of Oncology, June 2003, vol. 14, no. 11, p. 1607-1615. [CrossRef]

FLIS, Sylwia; GNYSZKA, Agnieszka; MISIEWICZ-KRZEMIŃSKA, Irena and SPLAWIŃSKI, Jacek. Decytabine enhances cytotoxicity induced by oxaliplatin and 5 -fluorouracil in the colorectal cancer cell line Colo-205. Cancer Cell International, April 2009, vol. 27, no. 9, p. 1-10. [CrossRef]

GREVER, M.C.B. Cancer drug discovery and development. In: DE VITA, V.H.S. and ROSENBERG, S.A., eds. Cancer: Principles and practice of oncology. Philadelphia, Lippincott Raven, 2001, p. 328-339.

HOU, Yu-Yi; WU, Mu-Ling; HWANG, Yu-Chun; CHANG, Fang-Rong; WU, Yang-Chang and WU, Chin-Chung. The natural diterpenoid ovatodiolide induces cell cycle arrest and apoptosis in human oral squamous cell carcinoma Ca9-22 cells. Life Sciences, July 2009, vol. 85, no. 1-2, p. 26-32. [CrossRef]

KIM, Seo Young; KIM, Seol Hee; KIM, Joo Young; BAE, Hyun Jin; YI, Hwaseon; YOON, Hong; KOO, Bon Sung; KWON, Moosik; CHO, Jae Youl; LEE, Choong Eun and HONG, Sungyoul. Surfactin from Bacillus subtilis displays anti-proliferative effect via apoptosis induction, cell cycle arrest and survival signaling suppression. FEBS Letters, March 2007, vol. 581, no. 5, p. 865-871. [CrossRef]

KREBS, K.G.; HEUSSER, D. and WIMMER, H. Spray reagents. In: STAHL, E. ed. Thin-Layer Chromatography: A laboratory handbook. $2^{\text {nd }}$ ed. Heidelberg, Springer-Verlag, 1969, p. 854-905.

KUMAR, Sharad. Caspase function in programmed cell death. Cell Death and Differentiation, January 2007, vol. 14, no. 1, p. 32-43. [CrossRef]

OHBA, Michio; MIZUKI, Eiichi and UEMORI, Akiko. Parasporin, a new anticancer protein group from Bacillus thuringiensis. Anticancer Research, January 2009, vol. 29, no. 1, p. 427-433.

PETERS, G.J.; BACKUS, H.H.; FREEMANTLE, S.; VAN TRIEST, B.; CODACCI-PIASANELLI, G.; VAN DER WILT, C.L.; SMID, K.; LUNEC, J.; CALVERT, A.H.; MARSH, S.; MCLEOD, H.L.; BLOEMENA, E.; MEIJER, S.; JANSEN, G.; VAN GROENINGEN, C.J. and PINEDO, H.M. Induction of thymidylate synthase as a 5-fluorouracil resistance mechanism. Biochimica et Biophysica Acta, July 2002, vol. 1587, no. 2-3, p. 194-205. [CrossRef]

SASSAKI, Guilherme L.; SOUZA, Lauro M.; CIPRIANI, Thales R. and IACOMINI, Marcello. TLC of carbohydrates. In: WAKSMUNDZKA-HAJNOS, Monika; SHERMA, Joseph and KOWALSKA, Teresa, eds. Thin layer chromatography in phytochemistry. Boca Raton, FL., CRC Press, Taylor \& Francis, 2008. p. 255-276.

SHOUGANG, Jiang; YUANGANG, Zu; YUEJIE, Fu; YU, Zhang and THOMAS, Efferth. Activation of the mitochondria-driven pathway of apoptosis in human PC-3 prostate cancer cells by a novel hydrophilic paclitaxel derivative, 7-xylosyl-10-deacetylpaclitaxel. International Journal of Oncology, July 2008, vol. 33, no. 1, p. 103-111. 
Phonnok et al.

THANOMSUB, Benjamas; POOMEECHOCKCHAI, Wanna; LIMTRAKUL, Anirut; ARUNRATTIYAKORN, Panarat; PETCHLEELAHA, Wipawan; NITIDA, Teruhiko and KANZAKI, Hiroshi. Withdrawn: Chemical structures and biological activities of rhamnolipids produced by Pseudomonas aeruginosa B189 isolated from milk factory waste. Bioresource Technology, March 2006, vol. 98, no. 5, p. 1149-1153. [CrossRef]

World Health Organization. Table 2: Cause-specific mortality and morbidity. In: World Health Statistics, 2009. WHO Statistical Information System (WHOSIS), 2009. Available from internet: http://www.who.int/whosis/whostat/2009/en/index.html.

ZHIVOTOSKY, Boris and ORRENIUS, Sten. Chapter 18: Cellular Aging and Death. Assessment of apoptosis and necrosis by DNA fragmentation and morphological criteria. Current Protocols in Cell Biology, November 2001, Appendix 18, Unit 18.3. [CrossRef]

\section{How to cite this article:}

PHONNOK, S.; UTHAISANG TANECHPONGTAMB, W.; THANOMSUB WONGSATAYANON, B. Anticancer and apoptosis-inducing activities of microbial metabolites. Electronic Journal of Biotechnology, September 2010, vol. 13, no. 5. http://dx.doi.org/10.2225/vol13-issue5-fulltext-7

Note: Electronic Journal of Biotechnology is not responsible if on-line references cited on manuscripts are not available any more after the date of publication. Supported by UNESCO / MIRCEN network. 